\title{
Observations on Seasonal Dynamics in Diet Composition of the Field Vole, Microtus agrestis, with Some Methodological Remarks
}

\author{
Jack FABER ${ }^{1}$ \& Wei-chun MA
}

\begin{abstract}
Faber J. \& Ma W., 1986: Observations on seasonal dynamics in diet composition of the field vole, Microtus agrestis, with some methodological remarks. Acta theriol., 31, 35: 479-490 [With 4 Tables \& 1 Fig.] The field vole, Microtus agrestis, was studied with regard to diet composition throughout the year. Vole populations were sampled in two grassland habitats, and stomach contents of captured animals were examined microscopically. The composition of the diet varied with season, both qualitatively and quantitatively. Grasses made up the bulk food in each habitat, the relative amount eaten reaching maximum values in the winter and prevernum period. Herbs and mosses were taken in considerable proportions as well, particularly in spring and summer, when their availabilities and palatabilities are high. Despite this congruity in seasonal compositions of vegetation and diet, $M$. agrestis exhibited occasionally a clear preference for less common food plants. A quantitative evaluation of the diet analysis was established by mean surface area and mean fresh weight estimates of specified food items. Only in the case of dicotyledonous plants did these estimates aberrate from each other, the mean fresh weight estimate generally being lower. This is considered to indicate lower passage rates through the intestinal tract, resulting in an overestimation of the relative amount of the particular food, when simply mean surface area is calculated. It is concluded that both estimates should be used simultaneously when herbs and green parts of shrubs are involved in the voles diet.

[Research Institute for Nature Management, P.O.Box 9201, 6800 HB Arnhem, The Netherlands]
\end{abstract}

\section{INTRODUCTION}

Data on the feeding habits of the field vole, Microtus agrestis L., are scarce and restricted, covering only parts of its distribution (Myllymäki, 1959c; Hansson, 1971a; Ferns, 1976; Larsson \& Hansson, 1977). Furthermore, seasonal differences in food habits have only been studied by Godfrey (1953), Evans (1973) and Hansson (1971b). It was shown that this vole species primarily eats leaves and stems of grasses, secondarily other plants groups like dicotyledons, mosses and pseudograsses, but that a considerable variability can be found, depending on the kind of ha-

${ }_{1}$ Present address: Dept. of Biology, Free University, De Boelelaan 1087, 1081 IV Amsterdam, The Netherlands. 
bitat and time of year. However, there are no data relating to populations of $M$. agrestis in the Netherlands, which fact therefore was one of the instigations for the present study. The study was carried out as part of an extensive research program on the flow of heavy metals through terrestrial food chains. The consequences of differences in diet composition for heavy metal burden of the consumers - due to a different heavy metal content of various food items - will be discussed elsewhere (Ma \& Faber, submitted).

With respect to a direct measurement of the diet composition of small mammals, no satisfactory method exists. However, indirect microscopic examination of droppings or stomach and gut contents can reveal much about the food taken. In case of a herbivorous animal, like the field vole, most consumed parts of plants can be identified by morphological features of the epidermis, as demonstrated by the pioneering work of Baumgartner \& Martin (1939) and Dusi (1949). After an exhaustive study of methodology, Hansson (1970) concluded that the best technique for diet analysis for small mammals is a combination of qualitative analysis (frequency of occurrence of relative occurrence) and quantitative volume estimates of stomach contents. Given the legitimacy of this conclusion, we consider some additional remarks on quantitative diet analysis by volume estimates useful for future investigations.

\section{RESEARCH SITES}

The grassland habitats under study were located near Budel $\left(51^{\circ} 41^{\prime}\right.$ $\left.31^{\prime \prime} \mathrm{N}, 5^{\circ} 34^{\prime} 47^{\prime \prime} \mathrm{E}\right)$ and near Arnhem ( $\left.52^{\circ} 01^{\prime} 02^{\prime \prime} \mathrm{N}, 5^{\circ} 52^{\prime} 54^{\prime \prime} \mathrm{E}\right)$.

The Budel site, located in the vicinity of a zinc processing plant, has recently undergone reclamation. In 1981 it was ploughed and treated with nitrogen, chalk and chicken slurry. Young deciduous trees were planted (including Quercus robur L., Acer platanoides L. and Robinia pseudoacacia L.). In addition, several Leguminosae were sown, e.g. Cytisus scoparius (L.) Link and Trifolium L. species, but these gradually disappeared. The vegetation is dominated by grasses. On a Tansley scale, Agrostis capillaris L. and Holcus lanatus are very abundant, while Poa angustifolia L. is abundant, and Elymus repens (L.), P. pratensis L. and some forb species are frequent. In all, the number of plant species present in the field adds up to 46 .

The Arnhem site is a storm blown clearing (1973) amidst deciduous and coniferous woodland $(Q$. robur, Betula pendula Roth and Pinus sylvestris L.). The site shows a grassland vegetation with very abundant Deschampsia flexuosa (L.) Trin., abundant Vaccinium myrtillus L., and frequent Hypnum cupressiforme Hedw. All together, 15 plant species could be found. 


\section{METHODS}

\subsection{Vole Trapping}

During 1984-1985 voles were caught with snap-traps, baited with a mixture of bacon and peanutbutter (since shrews and mice were also objectives of the research program, an "universal" bait had to be used to attract all three groups of mammals. In a pilot study this particular mixture for baiting yielded best results). Working at both sites simultaneously, trapping periods were June 6-21 ("spring"), August 13-30 ("summer"), October 15-25 ("autumn"), December 6-20 ("winter") and March 2-23 ("prevernum"). The prevernum period, just at the start of the vegetation period when plant growth is not yet visible, was described as critical for small rodents with respect to food (Górecki \& Gębczyńska, 1962). Traps were placed in lines or circles, in runways or at feeding places, and were checked twice a day during summertime, while only once a day in wintertime. Vole samples were frozen at $-20^{\circ} \mathrm{C}$ and stored till dissection.

Table 1

Trapping results for Microtus agrestis over the various periods: total number of catches in the whole period $(n)$, and relative number of catches $(\%)$ based on 100 traps over the first 24 hours.

\begin{tabular}{|c|c|c|c|c|c|c|c|c|c|c|}
\hline \multirow{2}{*}{ Site } & \multirow{2}{*}{\multicolumn{2}{|c|}{$\begin{array}{l}\text { Spring } \\
\mathrm{n}\end{array}$}} & \multicolumn{2}{|c|}{ Summer } & \multicolumn{2}{|c|}{ Autumn } & \multirow{2}{*}{\multicolumn{2}{|c|}{$\begin{array}{l}\text { Winter } \\
\mathrm{n}\end{array}$}} & \multicolumn{2}{|c|}{ Prevernum } \\
\hline & & & $\mathrm{n}$ & $\%$ & $\mathrm{n}$ & $\%$ & & & $\mathrm{n}$ & $\%$ \\
\hline Budel & 22 & 26.0 & 29 & 14.0 & 20 & 11.0 & 17 & 5.0 & 33 & 10.0 \\
\hline Arnhem & 13 & 6.0 & 14 & 3.8 & 19 & 5.0 & 5 & 1.8 & 8 & 0 \\
\hline
\end{tabular}

A reliable estimation of population density cannot be made with this trapping method (Stickel 1948; IBP 1971), but relative abundance at both sites was deducted from the number of catches (\%) in all traps placed over a 24-hours period at a particular spot. It appears that the numbers of Microtus agrestis in Budel were at least a twofold of those in Arnhem, with a maximum catching percentage in spring (Table 1). A description of both vole populations concerning body weight distribution and sexual maturing is provided by Ma \& Faber (submitted).

\subsection{Diet Micro-analysis}

The stomach contents of snap-trapped voles were examined microscopically, to determine their diet throughout the year. The stomach content was suspended in 10 volumes of water. Two drops of this suspension were placed separately on a hemocytometer (Bürker-Türk; ${ }^{1} / 400 \times 1{ }_{25} \mathrm{qmm}$, 


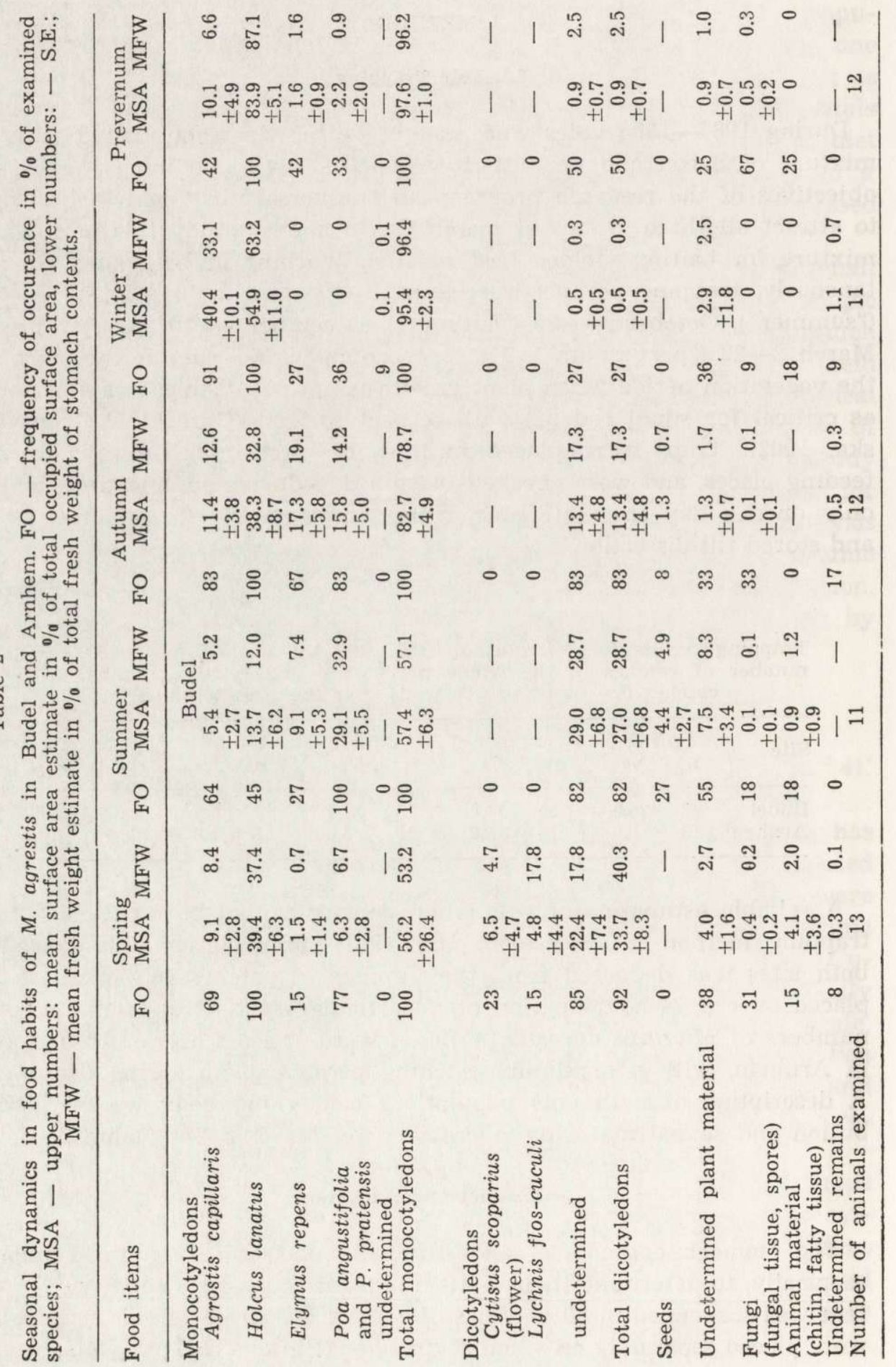




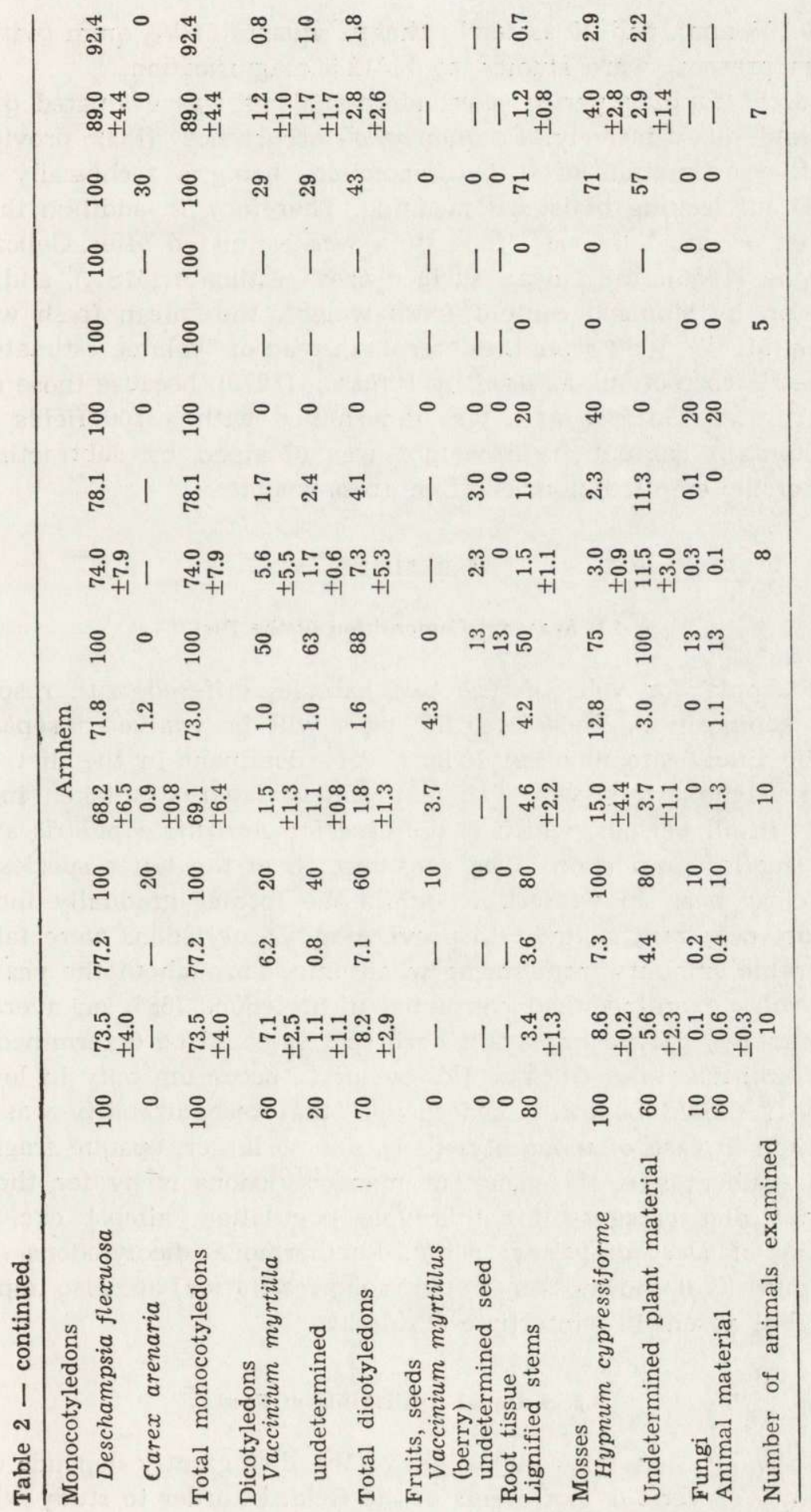


depth $0.100 \mathrm{~mm}$ ), and 20 aselectly chosen squares of $1 / 16 \mathrm{qmm}$ (with food particles present) were studied at $\times 312.5$ magnification.

For each trapping period, diet micro-analysis was evaluated qualitatively and quantitatively. Frequency of occurrence (FO) provided a qualitative estimation of diet composition, being a technically sound method, but lacking biological meaning. Therefore, in addition the surface area occupied by each food item was estimated after Gębczyńska \& Myrcha (1966): the "mean surface area" estimate (MSA), and, after conversion by stomach content fresh weight, the "mean fresh weight' estimate (MFW). We prefer these terms instead of "volume estimate" and "volumetric correction" as used by Hansson (1970), because those can be misinterpreted. Surface area was determined with a 100 fields ocular grid. Stomach content fresh weight was obtained by subtracting the weight of the emptied stomach from gross weight.

\section{RESULTS}

\subsection{Seasonal Composition of the Diet}

Food supply for voles in the two habitats differed with respect to species composition. Therefore, the sites will be evaluated separately.

At the Budel site monocotyledons were dominant in the diet of the voles throughout the year (Table 2): Holcus lanatus is taken in great amounts in all periods, which is the case for Agrostis capillaris as well, but to smaller proportions. The consumption of the latter species exhibits a clear peak in wintertime, while the former gradually increases in importance from summer to prevernum. Dicotyledons were taken in considerable amounts from spring to autumn. Throughout the year most of the voles examined had consumed dicotyledons $(68 \%$ on average of all specimens), but no important herb species could be determined, both Cytisus scoparius and Lychnis flos-cuculi L. occurring only in low frequency. It should be mentioned though, that recognizability was much lower than in case of monocotyledons, due to larger, opaque fragments. At the Arnhem site, the group of monocotyledons is by far the most important diet category for this vole population, almost exclusively consisting of Deschampsia flexuosa. Furthermore, dicotyledons (Vaccinicum myrtillus) and mosses (Hypnum cupressiforme) are also important groups, but absent in wintertime (Table 2).

\subsection{Seasonal Availability of Food}

It is obvious that the composition of the diet greatly depends on the availability of various food items in the field. In order to study whether 
a preference for certain items exists, the composition of the available food must be known. Table 3 shows the seasonal availability and the developmental state of plant species taken as food by Microtus agrestis. It appears that, in a qualitative respect, both abundant and occasional plant species are eaten.

Table 3

Seasonal availability and developmental state of plant species taken by Microtus agrestis.

\begin{tabular}{|c|c|c|c|c|c|c|}
\hline Species & Abundance & Spring & Summer & Autumn & Winter & Prevernum \\
\hline \multicolumn{7}{|c|}{ Budel } \\
\hline Agrostis capillaris & 5 & di,v & $\mathrm{fr}, \mathrm{v}$ & $\dagger, v$ & $\dagger, v$ & $\mathrm{v}$ \\
\hline Holcus lanatus & 5 & $\mathrm{fl}, \mathrm{v}$ & $\mathrm{fr}, \mathrm{v}$ & $t, v$ & $t, v$ & $\mathrm{v}$ \\
\hline Poa angustifolia & 4 & di,v & $f r, v$ & $t, v$ & $t, v$ & $\mathrm{v}$ \\
\hline Elymus repens & 3 & di,v & $\mathrm{fr}, \mathrm{v}$ & $t, v$ & $t, v$ & $\mathrm{v}$ \\
\hline Poa pratensis & 3 & $\mathrm{di}, \mathrm{v}$ & fr,v & $t, v$ & $t, v$ & $\mathrm{v}$ \\
\hline Lychnis flos-cuculi & 2 & fi & fr & $\mathrm{v}$ & $\mathrm{v}$ & v \\
\hline Cytisus scoparius & 2 & fl & fr & fr & $\mathrm{v}$ & $\dagger$ \\
\hline
\end{tabular}

$$
\text { Arnhem }
$$

$\begin{array}{lllllll}\text { Deschampsia flexuosa } & 5 & \mathrm{di} & \mathrm{fl} & \mathrm{fr} & \mathrm{v} & \mathrm{v} \\ \text { Vaccinium myrtillus } & 4 & \mathrm{fl} & \mathrm{fr} & \mathrm{fr} & \mathrm{V} & \mathrm{v} \\ \text { Carex arenaria } & 2 & \mathrm{fr} & \mathrm{fr} & \mathrm{v} & \mathrm{v} & \mathrm{v} \\ \text { Hypnum cupressiforme } & 3 & \mathrm{v} & \mathrm{v} & \mathrm{V} & \mathrm{V} & \mathrm{V}\end{array}$

Tansley scale of abundance: $1=$ rare, 2 =occasional, $3=$ frequent, $4=$ abundant, $5=$ = very abundant;

Developmental state: $\mathrm{di}=$ developing inflorescence, $\mathrm{fl}=$ flowering, $\mathrm{fr}=$ fructificating, $\mathrm{v}=$ vegetative, $\dagger=$ dead;

\section{DISCUSSION}

\subsection{Seasonal Dynamics in Diet Composition}

In order to compare the diets of the two vole populations, the food items shown in Table 2 are grouped into categories (Fig. 1), so that differences in species composition in the Budel and Arnhem vegetations become of little importance. It appears that Microtus agrestis is an unspecialized opportunistic feeder, concentrating predominantly on common plant species. Grasses make up the bulk food in both habitats and become of maximum importance during the winter-prevernum period. This is in agreement with data from Hansson (1971a) and Niethammer \& Krapp (1982). An exception to this rule is documented by Myllymäki (1959), who found that in southern Finland $M$. agrestis took herbs in favour of available grasses and sedges. Our results indicate only a seasonal preference for less common plant species (Lychnis, Cytisus; Hyp- 


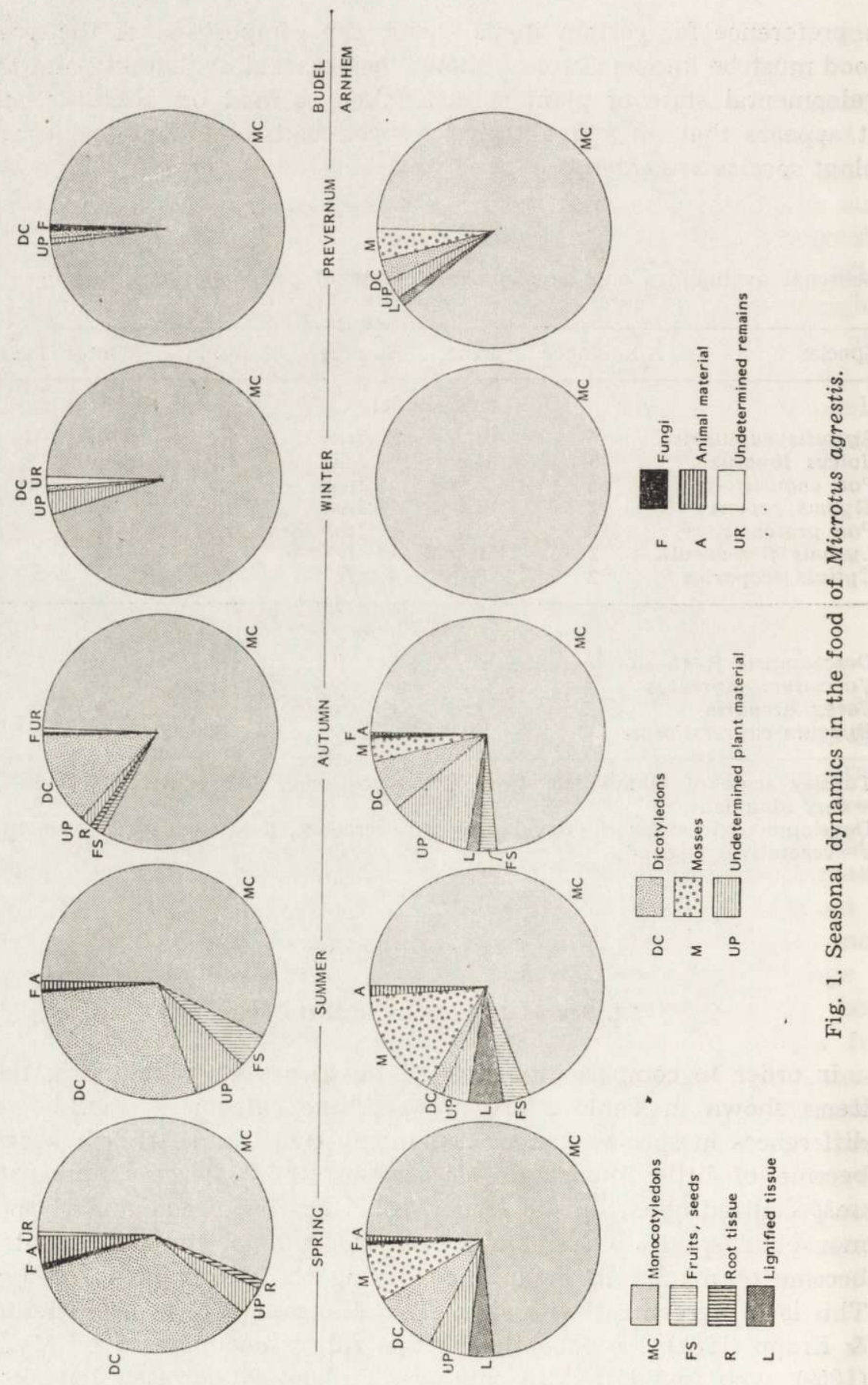


nun), which means that they are taken more frequently than would be expected from their relative abundance in the habitat. This is comparable to data submitted by Evans (1973; preference for Brachypodium sylvaticum) and Larsson \& Hansson (1977; preference for Festuca rubra and Achillea millefolium and probably also Deschampsia flexuosa and Rarunculus sp.). From these data it appears that both grasses and herbs can be selected for, with a tendency for moss and herbs to be selected mo:e in spring and summer, whereas grasses are more favoured in autumn and winter.

The degree of availability of plant groups at both sites also explains unequal utilization by the vole populations, the group of mosses even being absent in the Budel vegetation. However, the abundance of dicotyledons as a group is comparable for both vole populations. Unpalatability of several species in the Arnhem vegetation might probably be the explanation for this "negative selection": here the group of dicotyledons comprises several shrub species while at the Budel site many more herbs are found. By contrast, the observed different "seasonal preference" for various grass species as manifested by the Budel vole population might be explained in terms of palatability when considering the developmental state of the food plant (Table 3 ).

\subsection{Quantitative Analysis of Stomach Contents}

We used two estimates to reveal the mean composition of stomach contents of a sample from two field vole populations (after Gębczyńska \& Myrcha 1966). Mean fresh weight (MFW) was computed for every food item to account for different rates of passage through the digestive tract. Green food passes 2.5-3.0 times faster than seeds (Kostelecka-Myrcha \& Myrcha 1961). Also, large and hard particles remain longer in the tract. The mean surface area (MSA) estimate will overvalue slow passing ford items, since these remain longer in the stomach. However, such particles will be more common in stomachs with little content than in well-filled stomachs. Thus, the MFW estimate will be smaller than the rough mean of surface area percentages. On the other hand, rapidly passing food items will be overestimated when computing MFW (Table 4).

A comparison of both estimates was made by Hansson (1970) for $M$. agrestis. He found no pronounced differences, and concluded that in this species, therefore, the different retentions seem quantitatively unimportant. However, from our data it is evident that such differences can occur, especially within the group of dicotyledons. Hansson's study was based on vole populations which were caught in October and had eaten only very few dicotyledons by that time of year. Therefore, at 
this moment we must conclude that using the two estimates at one time can be necessary under certain conditions.

In our observations, dicotyledon fragments were generally larger than the average particle, and can be expected to remain in the stomach over a longer period of time. The MSA estimate would overrate a value for

Table 4

Reliability of quantitative evaluation of diet composition by estimating mean surface area (MSA) and mean fresh weight (MFW).

\begin{tabular}{lcc}
\hline & Passing rate of food items through & intestinal tract \\
\cline { 2 - 3 } & slow & rapid \\
\hline MSA & overestimation & good \\
MFW & good & overestimation \\
\hline
\end{tabular}

MFW when indeed these fragments would be most common in stomachs with little content (see above). This, however, is not always consistent with the facts, as is obvious from data for Lychnis flos-cuculi (Table 2). This herb was eaten by two vole specimens that had extremely heavy stomach content fresh weights. But since the frequency of occurrence of Lychnis was only $15 \%$, we refrain from any concluding remarks on this discrepancy. More research is needed to reveal the extent of specific differences within (bio-)systematical groups of diet items in the rate of passage through the alimentary tract of Microtidae.

\section{REFERENCES}

1. Baumgartner L. L. \& Martin A. C., 1939: Plant histology as an aid in squirrel food-habits studies. J. Wildl. Manage., 3: 266-268.

2. Dusi J. L., 1949: Methods for the determination of food habits by plant microtechniques and histology and their application to cottontail rabbit food habits. J. Wildl. Manage., 13: 295-298.

3. Evans D. M., 1973: Seasonal variations in the body composition and nutrition of the vole, Microtus agrestis. J. Anim. Ecol., 42: 1-18.

4. Ferns P. N., 1976: Diet of a Microtus agrestis population in South West Britain. Oikos, 27: 506-511.

5. Gębczyńska Z. \& Myrcha A., 1966: The method of quantitative determining of the food composition of rodents. Acta theriol., 11: 385-390.

6. Godfrey G. K., 1953: The food of Microtus agrestis in Wytham Berkshire. Saugetierk. Mitt., 1: 148-151.

7. Górecki A. \& Gębczyńska Z., 1962: Food conditions for small rodents in a deciduous forest. Acta theriol., 6: 275-295.

8. Hansson L., 1970: Methods of morphological diet micro-analysis in rodents. Oikos, 21: 255-266. 
9. Hansson L., 1971a: Habitat, food and population dynamics of the field vole Microtus agrestis L.) in South Sweden. Viltrevy, 8: 267-378.

10. Hansson L., 1971b: Small rodent food, feeding and population dynamics. A comparison between granivorous and herbivorous species in Scandinavia. Oikos, 2: 193-198.

11. BP, 1971: Proceedings of the IBP meeting on secondary productivity in small nammal populations, Helsinki, Finland, 28-29 August 1970. Ann. Zool. Fennici, 8.

12. Johnson M. K., Wofford H. \& Pearson H. A., 1983: Digestion and fragmentation: influence on herbivore diet analysis. J. Wildl. Manage., 47: 877-879.

13. Kostelecka-Myrcha A. \& Myrcha A., 1964: The rate of passage of foodstuffs hrough the alimentary tracts of certain Microtidae under laboratory conditions. Acta theriol., 9: 37-53.

14. Larsson T. B. \& Hansson L., 1977: Vole diet on experimentally managed afJorestation areas in northern Sweden. Oikos, 28: 242-249.

15. Ma Wei-chun \& Faber J. H., (submitted): Concentration of heavy metals in jield voles Microtus agrestis in relation to body weight, season, and dietary metal burden.

16. Myllymäki A., 1959: Bedeutung und Ursachen der Mausefrasschaden in Finland. Valt. Maatalouskoetoiminnan Fulk., (Die Staatliche Landwirtschaftliche Versuchstätigkeit Veröffentlichung), 178: 75-100.

17. Niethammer J. \& Krapp F., 1982: Handbuch der Saugetiere Europas. Band 1, Nagetiere I. Akademische Verlagsgesellschaft, Wiesbaden.

18. Phillipson J. M., Sarrazin-Comans S. M. \& Stomatopoulos C., 1983: Food consumption by Microtus agrestis and the unsuitability of feacal analysis for the determination of food preference. Acta theriol., 28: 397-416.

19. Stickel L. F., 1948: The trap-line as a measure of small mammal populations. J. Wildl. Manage., 12: 153-161.

Accepted, February 28, 1986

Jack FABER i Wei-chun MA

\section{OBSERWACJE SEZONOWYCH ZMIAN W SKEADZIE DIETY NORNIKA BUREGO MICROTUS AGRESTIS ORAZ UWAGI METODOLOGICZNE}

\section{Streszczenie}

Badano skład diety nornika burego Microtus agrestis w ciągu roku. Zwierzẹta odławiano w dwu środowiskach łąkowych, zawartość żołądków poddawano analizie mikroskopowej. Skład diety w poszczególnych sezonach zmieniał się jakościowo i ilościowo. W obu środowiskach podstawą pokarmu były trawy, a ich relatywna ilość osiągała maximum w zimie i na przedwiośniu. Zioła i mchy były również często zjadane, szczególnie latem i jesienią, gdy ich dostępność i jakość były wysokie. Pomimo tej zgodności pomiędzy sezonowym występowaniem roślinności a dietą, $M$. agrestis niekiedy wyraźnie preferowal mniej pospolite rośliny. 
Ilościowa ocena składu diety przeprowadzona zostala na podstawie ṡredniej powierzchni w polu widzenia mikroskopu i średniej wartości świeżej masy szacowanych dla poszczególnych składników pokarmu. Tylko w przypadku roślin dwuliściennych obie szacowane wartości odbiegały od siebie - średnia świeża masa była zazwyczaj niższa. Jest to uznane za wskaźnik wolniejszego przechodzenia tych roślin przez przewód pokarmowy. Fakt ten powoduje przecenianie względnej ilości roślin dwuliściennych w pokarmie, gdy liczona jest tylko średnia powierzchnia. Postuluje się, aby w badaniach diety norników, które zjadają zioła i zielone części krzewów, obie metody były stosowane równolegle. 